\title{
ACRL Rare Books and Manuscripts
}

\section{Section Preconference}

The ACRL Rare Books and Manuscripts Section will hold its fifteenth annual preconference at the University of Virginia in Charlottesville, from June 30 to July 2, 1974, prior to the ALA Annual Conference in New York City. Special Collections-Their Conservation and Preservation is the theme for the preconference.

An all-day tour to the W. J. Barrow Research Laboratory and the W. J. Barrow Restoration Shop, in Richmond, Virginia, will highlight the preconference. Meetings will feature the problems and solutions of repairing and conserving special collections materials. Among the speakers will be Bernard F. Walker, Barrow Research Laboratory; George M. Cunha, New England Document Center; Jean Gunner, Hunt
Institute for Botanical Documentation; William Spawn, American Philosophical Society; and Lawrence Towner, Newberry Library.

C. Waller Barrett, noted collector and former president of the Bibliographical Society of America, will host a dinner for the conferees at his home. James Bear, Jr., curator and director of Monticello, will speak on the assembling of the Monticello Library.

Vesta Lee Gordon, of the Manuscript Department at the University of Virginia Library, is serving as chairman of the preconference planning committee. Further information and registration materials may be obtained from Beverly P. Lynch, Executive Secretary, ACRL, 50 E. Huron St., Chicago, IL 60611.

\section{Inside Washington}

No funds have been requested in the 1975 budget for the college library resources program, under-graduate instructional equipment, and library training and demonstration. This is consistent with the Office of Education's general higher education policy of moving away from institutional support toward student support. . . .

\section{-from "The Fiscal Year 1975 Budget," The Department of Health, Education and Welfare.}

Academic librarians may be enjoying their last fling with federal money this year if the administration refuses to fund college and university library programs next year.

While Washington has never squandered much largess on academic libraries, federal funds this year have already been pared to the lowest amount since 1970 and in next year's budget the White House (for the second year in a row) has requested no money at all for long-standing programs-the $\$ 5,000$ basic grants, the special purpose grants, library training programs and research and demonstration grants included under Title II of the Higher Education Act of 1965. ALA Washington Office

To add to this picture of fiscal misery, the Higher Education Act, itself a bare toehold on Capitol Hill for academic librarians, expires in 1975 and will need new authorization or rewriting. But congressional education staffers are busy this session wrestling with a new elementary and secondary education act and have few thoughts to spare on higher education. Many staff people would seem to agree with the HEW conclusion that federal assistance has been "marginal" and colleges probably won't miss it. Few have heard the plea of the university library director who moaned, "if nothing else, it kept me from falling any further behind."

Academic libraries are thus in danger of being caught in midstream. While few would quarrel with the judgment of economists William J. Baumol and Matityahu Marcus that the evidence shows clearly "the past rates of expansion in library expenditures, like those of educational institutions in general, could not have been expected to continue indefinitely," a consensus of where to turn next is needed.1

${ }^{1}$ William J. Baumol and Matityahu Marcus, Economics of Academic Libraries (Washington, D.C.: American Council on Education, 1973), p.1. 